\title{
Profile of Essential and Non-Essential Metals in Soil and in Khat (Catha Edulis Forsk) Leaves Cultivated in Southern Region, Ethiopia
}

\author{
Adane Desta, Almaz Ataklti \\ Department of Chemistry, College of Natural Science, Arbaminch University, Arbaminch, Ethiopia \\ Email address: \\ destaadane@gmail.com (A. Desta),ataklti.almaz@yahoo.com (A. Ataklti)

\section{To cite this article:} \\ Adane Desta, Almaz Ataklti. Profile of Essential and Non-Essential Metals in Soil and in Khat (Catha Edulis Forsk) Leaves Cultivated in \\ Southern Region, Ethiopia. American Journal of Physical Chemistry. Vol. 4, No. 6, 2015, pp. 58-64. doi: 10.11648/j.ajpc.20150406.13
}

\begin{abstract}
This study was conducted with the objective of determining the quantity of selected essential and nonessential metals; Co, Mg, Ca, Cu, Mn, Cr, Cd, Fe, Zn and $\mathrm{K}$ in the leaf and supporting soil of Khat (Catha edulis Forsk). Samples of three Khat types (Konso, Gidole and Koyra) and soils from their root zone collected from three different sites in southern Ethiopia region were analyzed by flame atomic absorption spectrometry. $\mathrm{K}$ in soil and Khat sample were also determined by flame atomic emission spectroscopy. Known weight of oven-dried Khat samples were wet-digested using $2 \mathrm{~mL}$ of (69-72\%) $\mathrm{HNO}_{3}$ and $2 \mathrm{~mL}$ of $(70 \%) \mathrm{HClO}_{4}$ for $130 \mathrm{~min}$ at variable temperatures $\left(120-268{ }^{\circ} \mathrm{C}\right)$. Soil was digested by the procedure, $0.5 \mathrm{~g}$ samples of soil were digested with concentrated nitric acid, concentrated hydrochloric acid and hydrogen peroxide, using Kjeldahl digestion block under reflux condenser for $3 \mathrm{~h}$ at $300{ }^{\circ} \mathrm{C}$. Both the edible portion of khat leaves and the soils of the study farms showed similar accumulation patterns to some extent, in their contents of the studied macro and micronutrients. Regression analysis and pearson correlation ( $\mathrm{r}$ ) results show a positive correlation Coffecient $\left(\mathrm{R}^{2}\right)$ values ranging from 0.281 up to 0.991 and for pearson correlation (r) values ranging from $0.244-0.951$. Although regressions based on the pooled data from the three Khat types are not adequately correlated with total metal soil levels, better fits were obtained when regression models were used for Konso Khat separately. However, no strong correlations between the leaves and other variables are evident except for $\mathrm{Ca}$ and $\mathrm{Mg}$ metal contents which have $\mathrm{r}$ values of 0.971 and 0.991 respectively with ( $\mathrm{p}<0.01)$ levels. The concentrations of the metals were also compared with recommended maximum permissible limits and some international reports.
\end{abstract}

Keywords: Khat, Metals, Soil, Flame Atomic Absorption Spectrometer, Southern Ethiopia

\section{Introduction}

Fresh leaves of khat (Catha edulis Forsk) are customarily chewed by the inhabitants of East Africa and Southern Arabia to attain a state of stimulation. Its young leaves and stem tips contains higher proportions of cathine and cathinone, which are responsible for much of the stimulant effect of khat. Khat chewing is highly prevalent in East African and some Middle Eastern countries. Its use is both a social and a culture-based activity and it is said to enhance social interaction. On average, almost $70 \%$ of households in Yemen and $50 \%$ in Djibouti use khat (Milanovic, 2008). It was reported in a Somalia-based study that approximately $36.4 \%$ of people had chewed Khat and more than $30 \%$ of Ethiopians have been reported to use khat (Belew et al.,
2000). The overall prevalence of khat chewing in various regions of Ethiopia is well documented; among upper secondary school students $64.9 \%$, in a rural community in southern Ethiopia $50 \%$, at a university located northern Ethiopia, Axum $28.7 \%$, and in the Eastern Ethiopia $42.2 \%$ (ayenew et al., 2014 and Ephrem, 2010).

Studies on chemical composition of plant materials are growing as a result of ongoing developments in agriculture, nutrition, environmental studies, biogeochemical surveying and mineral prospects. All these developments have led to increased demands for analysis of complicated biological matrices. Various reports have discussed the potential health implications of trace metals in various plants and fruits, $\mathrm{Cd}$, $\mathrm{Pb}, \mathrm{Ni}$ and $\mathrm{Al}$, hereinafter referred to as toxic heavy metals and may pose a serious threat to plant, animal, human and environmental health, because they are not degradable by 
bio-process and remain in environment and passes to food chain. It is globally accepted that some heavy metals such as $\mathrm{Fe}, \mathrm{Zn}, \mathrm{Cu}$, and $\mathrm{Mn}$; hereinafter referred to as microelements; are essential for healthy growth and development within certain permissible limits. Macro-elements are of great biological importance despite their small contribution to the body weight, although excess intake of them can cause chronic toxicity in human. The determination of these elements in beverages, water, food, plant and soil is thus of outermost importance. One of the major food sources of these metals is green leafy vegetable (Anonymous, 1999 and Hagos et al, 2010).

In addition to plant materials, the analysis of soil is an important diagnostic tool for identifying nutrient deficiency or excess. Soil analysis has the advantage over the plant analysis as well as visual deficiency symptoms in indicating the extent of nutrient deficiency or their requirement for crops prior to seeding. The identification of macro and micro constituent, as well as contaminants and the establishment of hazards levels are only possible if the soil composition is known by using reliable and comparable chemical measurements (Das, 2007). Further, air, food and water pollution is widely anticipated and reported in industrialized and densely populated areas. In countries like Ethiopia, there is not enough industry to cause substantial pollution. The major source of contamination comes from agricultural activities, such as the application of fertilizers and pesticides. Hence, an increasingly important aspect of food quality should be to control the concentrations of trace metals in food.

Now days, important progress has been made in understanding the pharmacological and social effects of Khat. However, less attention has been paid to the chemical profile in Khat and their role in distributing trace element levels in human tissues and body fluids. Few papers has been reported on essential and non essential metals of Ethiopian Khat more specifically (Belew et al., 2000, Hagos et al., 2010, Ephrem, 2010, Minaleshewa et al., 2010, and Ayenew et al., 2014). However, correlations of elemental concentrations of Khat with its supporting soil are scarce in the literature. As this issue has not been much studied in Ethiopia the main aim of this study was to assess the profile of selected essential and nonessential metals in Khat leaves cultivated in southern region, Ethiopia with its supporting soil.

\section{Materials and Methods}

\subsection{Reagents and Chemicals}

An acid mixture of 1:1 conc. HNO3 (69\% LR, Breckland Scientific Supplies, U.K) and conc. $\mathrm{HClO}_{4}$ (69.0-72\%, Blulux, Laboratory reagent) was used for digestion Khat samples. Concentrated $\mathrm{H}_{2} \mathrm{SO}_{4}(98 \%$, laboratory reagent, LOBA, India) and Selenium powder $(99 \%$, Breckland Scientific Supplies, U.K) were used in the optimization for Khat digestion process. A solution of $\mathrm{LaCl}_{3} \cdot 7 \mathrm{H}_{2} \mathrm{O}(99.9 \%$,
Blulux, Laboratory PVT Ltd.) was used in the determination of $\mathrm{Ca}$ and $\mathrm{Mg}$. $\left(\mathrm{NH}_{4}\right)_{2} \mathrm{Fe}\left(\mathrm{SO}_{4}\right)_{2} \cdot 6 \mathrm{H}_{2} \mathrm{O}(99 \%)$ and $\mathrm{K}_{2} \mathrm{Cr}_{2} \mathrm{O}_{7}$ (99.5\%) (Blulux, Laboratory reagent), conc. Orthophosphoric acid (85-88\%, Blulux, Laboratory reagent), and bariumdiphenyl amine sulphonate (BDH chemicals Ltd, England) solutions were used to determine soil organic matter. $\mathrm{HCl}, \mathrm{NaOH}, \mathrm{CaCO}_{3}$ powder and phenolphthaline indicator solution were used for the determination of $\mathrm{CaCO}_{3}$ percent content of the soil. $\mathrm{KCl}(99.5 \%$, Analytical reagent, CDH (P) LTD, India) was used for soil acidity determination.

\subsection{Equipments}

A water deionizer (Elgalan Instrument, UK) was used to produce deionized water. Digital analytical balance (Explorer, Ohaus, Model E11140, Switzerland) with \pm 0.0001 $\mathrm{g}$ precision were used for all measurements of samples. The samples of Khat and soil were digested in a digestion tube using Kjeldahl digestion block. Atomic flame absorption spectrophotometer (Model 210/211 VGP Buck Scientific AAS VER 3.74) was used to determine metal concentration in the samples. Flame atomic emission spectroscopy (Ciba Corning Diagnostics Scientific Instruments M410, U.K) was used to determine $\mathrm{K}$ metal concentration in the aforementioned samples. Digital $\mathrm{pH}$ meter (ELE International PQ qualab) was used to determine the $\mathrm{pH}$ of soil samples after stirring by a magnetic stirrer (Hanna instruments, model H1200, UK).

\subsection{Collection and Analysis of Samples}

Samples of Khat leaves and supporting soils were gathered from different sites of Gamo Gofa zone of Southern region of Ethiopia which are well known in producing, marketing Khat. Samples of different Khat types and its supporting soil from farms of local farmers were collected in Konso, Gidole and Koyra Sites. The three varieties of Khats were distigushed by the local farmers in the area based on their narcotic effect, exciting rate and colours. In order to avoid any confounding differences in the environmental factorssuch as type of soil and fertilizers, irrigation system and humidity-that may affect the chemical composition of the Khat leaves, the samples were collected from different places of each region and pooled together. The upper recently mature leaves free of physical damage and injury from insects and of fungal infestation were selected for this study. The Soil samples were collected from surface soils close to the each Khat varieties $(0-30 \mathrm{~cm}$ depth) and brought to the laboratory wrapped in polyethylene bags. In the laboratory, the khat leaves were washed with deionised water. The leaves were dried at room temperature. The dried samples of khat and soil were then separately grinded to fine size using two sequential millers; Mill one (2.00 mm mesh size) and Mill two $(1.00 \mathrm{~mm}$ mesh size). The powders were subsequently stored in clean polyethylene bags until digestion. To avoid cross contamination, the stainless steel grinding system of the millers were washed with acetone after or before each grinding cycle. 


\subsection{Optimization of Digestion Procedure}

To select an optimum procedure for digestion, parameters like digestion time, reagent volume, volume ratio of reagents, and digestion temperature were optimized by varying one parameter at a time and keeping the others constant. Parameters giving clear solution at lower temperature, requiring minimum reagent volume and digestion time were selected as an optimum procedure for digestion of khat and soil samples.

\subsubsection{Digestion of Khat Samples}

The samples were digested following the procedure recommended by the (AOAC, 1990). About $1.0 \mathrm{~g}$ of ground and meshed Khat leaf samples in a clean dish were dried over night at $105{ }^{\circ} \mathrm{C}$ in an oven and then cooled in desiccator. $0.5 \mathrm{~g}$ portions were weighed and transferred into digestion tubes. 4 $\mathrm{mL}$ of conc. 1:1 $\mathrm{HNO}_{3}$ and $\mathrm{HClO}_{4}$ were added and swirled carefully to moisten the Khat sample and left to stand for $2 \mathrm{hrs}$. The digestion tubes were placed in a Kjeldahil block and heated between $120-268{ }^{\circ} \mathrm{C}$ for about $130 \mathrm{~min}$ in variable temperature. The tubes were removed and cooled to room temperature. To this, $45 \mathrm{ml}$ of deionized water was added and mixed thoroughly. This solution was left standing to cool at room temperature, mix again, filtrated on a $100 \mathrm{ml}$ volumetric flask, bringing to volume with distilled-deionized water and stored in a plastic bottles for the determination of metals. Triplicate digestions were carried out for each bulk sample.

The samples were analyzed after digestion for their metal contents of $\mathrm{Ca}, \mathrm{Fe}, \mathrm{Mn}, \mathrm{Cu}, \mathrm{K}, \mathrm{Zn}, \mathrm{Co}, \mathrm{Cr}, \mathrm{Mg}, \mathrm{Pb}$ and $\mathrm{Cd}$ by the Flame Atomic Absorption/Emission Spectrometer after an external calibration using aqueous calibration standards prepared from stock standard solutions of the respective elements in absorbance mode. Where, $\mathrm{K}$ in the sample digest was determined by emission mode flame photometer in order to avoid the ionization interference. Further, for $\mathrm{Ca}$ and $\mathrm{Mg}$ metals, excess of lanthanum was added to avoid the formation of refractory compounds that would depress the signal.

\subsubsection{Digestion of Soil Samples}

$1.0 \mathrm{~g}$ of soil was accurately weighted and transferred into $100 \mathrm{~mL}$ round bottom flask and moistened with $1 \mathrm{~mL}$ of distilled deionized water. $10 \mathrm{~mL}$ of 1:3 mixtures of conc. $\mathrm{HNO}_{3}$ and $\mathrm{HCl}$ was added to the flask and kept for hours until it got stabilized. Then, digested on Kjeldahl digestion block under reflux condenser for $2 \mathrm{~h}$ at $140{ }^{\circ} \mathrm{C}$. The digest was left to stand for $30 \mathrm{~min}$ to cool down to room temperature, then about $50 \mathrm{~mL}$ of distilled deionized water was added to flask, filtered through Whatman No. 1 filter paper in to $100 \mathrm{~mL}$ volumetric flask and made up to the mark with rinsing the digestion flask. The solutions were used for the analysis of the total soil metal concentrations for $\mathrm{Ca}, \mathrm{Fe}$, $\mathrm{Mn}, \mathrm{Cu}, \mathrm{K}, \mathrm{Zn}, \mathrm{Co}, \mathrm{Cr}, \mathrm{Mg}, \mathrm{Pb}$ and $\mathrm{Cd}$ by the Flame Atomic Absorption/Emission Spectrometer. The concentration of $\mathrm{K}$ was determined in emission mode of the spectrophotometer. Furthermore, $\mathrm{CaCO}_{3}$ Content, organic matter content and $\mathrm{pH}$ of the soil samples were analyzed in a suspension of a 1:1 soil: water mixture.

\subsection{Method Detection Limit}

To determine method detection limit, replicate analyses for all blank samples were performed, and the pooled standard deviation of the seven reagent blanks was calculated. The detection limits were obtained by multiplying the pooled standard deviation of the reagent blank by three. The results clearly show that the calibration curves with good correlation coefficients and lower method detection limits were obtained during the analysis.

\subsection{Evaluation of Analytical Method}

The efficiency of the optimized procedure was evaluated using recovery experiment, i.e., by the procedure as follow: $0.5 \mathrm{mg}$ of $\mathrm{K}, 0.1 \mathrm{mg}$ of $\mathrm{Ca}, 0.1 \mathrm{mg}$ of $\mathrm{Mg}$ which contains a total of $1.5 \mathrm{~mL}$ solution were spiked at once into a first digestion tube which has known weight Khat leaf sample and $0.5 \mathrm{mg}$ of $\mathrm{Fe}, 0.5 \mathrm{mg}$ of $\mathrm{Mn}, 0.5 \mathrm{mg}$ of $\mathrm{Cu}$ which has a total volume of $1.8 \mathrm{~mL}$ were spiked into a second digestion tube containing the same Khat sample. $0.75 \mathrm{mg}$ of $\mathrm{Zn}$ and $0.2 \mathrm{mg}$ of $\mathrm{Cd}$ were spiked in to a third digestion tube. The rest for $0.1 \mathrm{mg}$ of $\mathrm{Pb}, 0.1 \mathrm{mg} \mathrm{Cr}$ and $0.5 \mathrm{mg}$ Co were spiked into a fourth digestion tube. Each sample was determined for their respective spiked metals. Recovery test was also performed for soil samples using the same procedure. Each recovery test for both samples was performed in triplicate. The percentage recoveries of each sample are within the acceptable range.

\section{Results and Discussion}

\subsection{Method Validation}

Due to the absence of certified reference material for leaves and soil sample in the laboratory, the efficiency of the optimized procedure was checked by adding known concentration of each metal in khat leaves and supporting soil samples. The spiked and non-spiked samples were digested and analyzed in similar condition. Then the percentage recovery of the analyte was calculated by:

Recovery
$=\frac{C M \text { in the spiked samples }-C M \text { in the non spiked samples }}{\text { Amount added }} \times 100 \%$

Where, $\mathrm{CM}=$ concentration of metal of interest.

As shown in Table 1, the results of percentage recoveries for the studied metal nutrients in Khat leaves and supporting soil were all between 91 to $108 \%$ and 90 to $110 \%$ respectively except for recovery percent of $\mathrm{Ca}$ which gives a value of $112 \%$ in the leave. Therefore, this verifies that the optimized digestion procedure was valid (good accuracy) for Khat leaves and soil sample analysis.

\subsection{Levels of Selected Essential and Non-Essential Metals in Khat Leaf Samples}

In the present study the concentration of nine essential (K, $\mathrm{Ca}, \mathrm{Mg}, \mathrm{Mn}, \mathrm{Fe}, \mathrm{Cu}, \mathrm{Cr}, \mathrm{Zn}$ and $\mathrm{Co}$ ) and two non-essential $(\mathrm{Pb}$ and $\mathrm{Cd})$ metals in khat leave samples of the three 
varieties (Konso, Gidole and Koyra) were quantified.

Table 1. Recovery test for the optimized procedure of khat leave sample.

\begin{tabular}{llllll}
\hline Elements & Conc. in the sample (mg/kg) & Amount added (mg) & $\begin{array}{l}\text { Concentration in the spiked } \\
\text { sample }\end{array}$ & $\begin{array}{l}\text { Amount recovered } \\
\text { (mg) }\end{array}$ & Recovery (\%) \\
\hline $\mathrm{Ca}$ & $2.683 \pm 0.02 \mathrm{mg} / \mathrm{g}$ & 0.1 & $2.795 \pm 0.016 \mathrm{mg} / \mathrm{g}$ & 0.112 & $112 \pm 7$ \\
$\mathrm{Fe}$ & $741.67 \pm 0.13$ & 0.5 & $742.21 \pm 0.23$ & 0.54 & $108 \pm 2$ \\
$\mathrm{Mg}$ & $3.98 \pm 0.09 \mathrm{mg} / \mathrm{g}$ & 0.1 & $4.079 \pm 0.12 \mathrm{mg} / \mathrm{g}$ & 0.099 & $99 \pm 5.2$ \\
$\mathrm{Cr}$ & $7.5 \pm 0.5$ & 0.1 & $7.5097 \pm 1.2$ & 0.097 & $97 \pm 4$ \\
$\mathrm{~K}$ & $6.99 \pm 0.08 \mathrm{mg} / \mathrm{g}$ & 0.5 & $7.47 \pm 0.04$ & 0.48 & $96 \pm 2$ \\
$\mathrm{Cd}$ & $2.12 \pm 0.02$ & 0.2 & $2.30 \pm 0.01 \mathrm{mg} / \mathrm{g}$ & 0.189 & $94.5 \pm 3$ \\
$\mathrm{Zn}$ & $167.21 \pm 3.8$ & 0.75 & $167.9 \pm 6.5$ & 0.699 & $93.2 \pm 6.1$ \\
$\mathrm{~Pb}$ & $\mathrm{ND}$ & 0.1 & $0.09 \pm 0.0003 \mathrm{mg} / \mathrm{g}$ & 0.092 & $92 \pm 2.2$ \\
$\mathrm{Mn}$ & $36.02 \pm 0.29$ & 0.5 & $36.5 \pm 0.4$ & 0.46 & $92 \pm 1$ \\
$\mathrm{Cu}$ & $19.23 \pm 1.1$ & 0.2 & $19.41 \pm 0.89$ & 0.182 & $91 \pm 2.4$ \\
$\mathrm{Co}$ & $1.57 \pm 0.07$ & 0.1 & $2.49 \pm 0.21$ & 0.456 & $91.78 \pm 0.8$ \\
\hline
\end{tabular}

ND: not detectable.

As can be seen from the data in Table 2, there is a wide variation in concentration of macro-and micronutrients within and among the khat varieties. The most abundant metals among the macro elements was $\mathrm{K}$ followed by $\mathrm{Mg}$ and $\mathrm{Ca}$ whereas $\mathrm{Fe}$ contents of the Khat leaves was the predominant among the tested micronutrient heavy metals followed by $\mathrm{Zn}, \mathrm{Mn}, \mathrm{Cu}$ and $\mathrm{Cr}$. It can be deduced from the levels of all the metals in the studied Khat types of all varieties, that the concentrations of the macro and micro nutrient metals followed similar trend for all the sample sites.

Ayenew et al (2014) and Minaleshewa (2010) has reported the ranges for essencial and nonessencial metals of different Ethiopian Khat. In addition, Sailus (2014) has reported the nutrient concentrations in the Kenyan khat leaves. The pattern of concentration of elements in most of khat varieties obtained by Minaleshewa (2010), were in the order: $\mathrm{Ca}>\mathrm{Mg}>\mathrm{Fe}>\mathrm{Mn}>\mathrm{Zn}>\mathrm{Cu}>\mathrm{Cr}>\mathrm{Co}$, while $\mathrm{Cd}$ and $\mathrm{Pb}$ were below the method detection limit of his analysis. Sailus (2014) has also reported that the macro nutrient metal concentrations ranges; $\mathrm{K}$ (10.3-30.3 mg/g), Ca (9.44-33.2 $\mathrm{mg} / \mathrm{g}$ ) and $\mathrm{Mg}(1.14-7.19 \mathrm{mg} / \mathrm{g})$. The higher level of $\mathrm{K}$ in the studied Khat plants according to aforementioned people were due to the fact that nutrient elements such as N, P, K, S and $\mathrm{Mg}$ are highly mobile in plant tissue and translocated from old leaves to young leaves. It is also reported that a higher concentration of $\mathrm{Ca}$ and $\mathrm{Mg}$ in Khat samples and suggested that, this is due to a broad range of Ca-bearing minerals in soil and water which are usually abundant and can easily be absorbed by the plant.

Iron was the most abundant metal in Khat varieties among the tested heavy metals of all the sample sites ranging between $(573.33 \pm 5.62-741.67 \mathrm{mg} / \mathrm{kg})$ where the highst value is found for koyra Khat and the lowest value for Gidole Khat. The highest level of Fe in Khat plant is consistent with the highest amount of organic matter in all soils of Khat farms. According to Das (2007) and Hagos et al (2010) availability of iron to plant increases with organic matter contents of the soil. Iron reduction was greatly increased with the application of organic matter and the longer the period of submergence, the greater the amount of water soluble plus exchangeable iron.
The amount of zinc in Khat samples varies from 137 -203 $\mathrm{mg} / \mathrm{kg}$. The highest being for Koyra Khat and lower in Konso Khat. The concentrations of $\mathrm{Mn}, \mathrm{Cu}$ and $\mathrm{Cr}$ obtained are given as follows: $\mathrm{Mn}(27.206-85.29 \mathrm{mg} / \mathrm{kg}), \mathrm{Cu}(16.9-22.5$ $\mathrm{mg} / \mathrm{kg}$ ) and $\mathrm{Cr}(1.52-4.09 \mathrm{mg} / \mathrm{kg})$. The values of $\mathrm{Fe}, \mathrm{Mn}, \mathrm{Cr}$ and $\mathrm{Cu}$ in this work are comparable with the litrature reported values such as Yemeni, Kenyan and Ethiopian Khat leaves of different areas (Belew et al., 2000; Minaleshewa, 2010; Olowaya et al., 2010; Ayenew et al., 2014).

Moreover, the concentrations of toxic metals $\mathrm{Pb}$ and $\mathrm{Cd}$ in the studied Khat plant leaves were too low to be detected except for Cd present in Konso Khat. This may be due to the fact that there are insufficient factories in the studied areas to cause substantial pollution. As people may have some health problems which may restrict the consumption of electrolytes, knowing the level of these elements in samples consumed is critical. The toxic metals should be thoroughly surveyed in order to take any remedial actions. Control authorities in the national government positions should be aware of such issues and take appropriate measures.

Table 2. Average concentration (mean $\mathrm{mg} / \mathrm{kg}, \mathrm{mg} / \mathrm{g} \pm \mathrm{SD}, \mathrm{n}=3$ ) of metals in khat leaf samples.

\begin{tabular}{llll}
\hline \multirow{2}{*}{ Metals } & Sampling site & & \\
\cline { 2 - 4 } & Konso & Gidole & Koyra \\
\hline $\mathrm{Ca}(\mathrm{mg} / \mathrm{g})$ & $3.00 \pm 0.12$ & $2.81 \pm 0.03$ & $3.12 \pm 0.02$ \\
$\mathrm{Fe}(\mathrm{mg} / \mathrm{kg})$ & $676.67 \pm 3.65$ & $573.33 \pm 5.62$ & $741.67 \pm 7.12$ \\
$\mathrm{Mg}(\mathrm{mg} / \mathrm{g})$ & $4.530 \pm 0.11$ & $3.980 \pm 0.09$ & $4.576 \pm 0.01$ \\
$\mathrm{Cr}(\mathrm{mg} / \mathrm{kg})$ & $4.09 \pm 0.29$ & $2.75 \pm 0.32$ & $1.52 \pm 0.13$ \\
$\mathrm{~K}(\mathrm{mg} / \mathrm{g})$ & $15.37 \pm 0.48$ & $8.73 \pm 0.04$ & $13.79 \pm 0.32$ \\
$\mathrm{Cd}(\mathrm{mg} / \mathrm{kg})$ & $2.12 \pm 0.02$ & $* \mathrm{ND}$ & $* \mathrm{ND}$ \\
$\mathrm{Zn}(\mathrm{mg} / \mathrm{kg})$ & $136.423 \pm 1.8$, & $167.21 \pm 3.8$, & $202.64 \pm 2.21$ \\
$\mathrm{~Pb}(\mathrm{mg} / \mathrm{kg})$ & $* \mathrm{ND}$ & $* \mathrm{ND}$ & $* \mathrm{ND}$ \\
$\mathrm{Mn}(\mathrm{mg} / \mathrm{kg})$ & $85.29 \pm 1.36$ & $36.02 \pm 0.29$ & $27.206 \pm 0.3$ \\
$\mathrm{Cu}(\mathrm{mg} / \mathrm{kg})$ & $16.9 \pm 1.0$ & $22.5 \pm 1.4$ & $20.19 \pm 0.53$ \\
$\mathrm{Co}(\mathrm{mg} / \mathrm{kg})$ & $1.57 \pm 0.07$ & $0.324 \pm 0.05$ & $* \mathrm{ND}$ \\
\hline
\end{tabular}

*concentrations bellow detection limit of the procedure, ND: not detectable.

\subsection{Levels of Essential and Non-essential Metals Soil Samples}

Tables 3 shows the mean concentration values of each metal in each soil sample with its respective relative standard 
deviation (RSD) in dry-weight basis. it was shown that the macro, micro and toxic metal contents analyzed in the khat farm soils varied significantly from site to site. Among the macro elements, $\mathrm{K}$ content of the soils was higher within a range of $(7.26-12.06) \mathrm{mg} / \mathrm{g}$ followed by $\mathrm{Mg}(0.82-2.477)$ $\mathrm{mg} / \mathrm{g}$ and $\mathrm{Ca}(0.51-1.02) \mathrm{mg} / \mathrm{g}$. Fe from micro elements is the predominant metal with in the concentration range of (12.24 $37.2) \mathrm{mg} / \mathrm{g}$. These may be in good agreement with the analysis raised by Minaleshewa (2010), soils with low pH contain high amount of $\mathrm{Fe}$ and $\mathrm{Al}$ oxides. This is indicative of presence of excess amount of hematite $\left(\mathrm{Fe}_{2} \mathrm{O}_{3}\right)$. Further, Iron makes up about 5 percent by weight of the earth's crust and must be present in all soils. Common minerals of Fe are Olvine $\left[(\mathrm{Mg}, \quad \mathrm{Fe})_{2} \mathrm{SiO}_{4}\right], \quad$ Pyrite $(\mathrm{FeS}), \quad$ Siderite $\left(\mathrm{FeCO}_{3}\right)$, hematite $\left(\mathrm{Fe}_{2} \mathrm{O}_{3}\right)$, goethite $(\mathrm{FeOOH})$, magnetite $\left(\mathrm{Fe}_{3} \mathrm{O}_{4}\right)$ and ilmenite $\left(\mathrm{FeTiO}_{3}\right)$ (Das, 2007). Iron is absorbed by the plant as $\mathrm{Fe}^{2+}$ and it can be transported to root surfaces as iron chelates.

Table 3. Average metal concentrations (mean $\mathrm{mg} / \mathrm{kg}, \mathrm{mg} / \mathrm{g} \pm S D, n=3$ ) in the soils of selected khat growing farms.

\begin{tabular}{llll}
\hline \multirow{2}{*}{ Metals } & \multicolumn{3}{l}{ Sampling site } \\
\cline { 2 - 4 } & Konso & Gidole & Koyra \\
\hline $\mathrm{Ca}(\mathrm{mg} / \mathrm{g})$ & $1.02 \pm 0.06$ & $0.73 \pm 0.03$ & $0.51 \pm 0.07$ \\
$\mathrm{Fe}(\mathrm{mg} / \mathrm{g})$ & $12.24 \pm 0.61$ & $17.67 \pm 0.71$ & $37.24 \pm 0.86$ \\
$\mathrm{Mg}(\mathrm{mg} / \mathrm{g})$ & $2.477 \pm 0.1$ & $0.82 \pm 0.07$ & $1.12 \pm 0.02$ \\
$\mathrm{Cr}(\mathrm{mg} / \mathrm{kg})$ & $65.2 \pm 5.67$ & $43.68 \pm 4.02$ & $18.11 \pm 1.02$ \\
$\mathrm{~K}(\mathrm{mg} / \mathrm{g})$ & $12.06 \pm 0.6$ & $7.26 \pm 0.29$ & $7.29 \pm 0.34$ \\
$\mathrm{Cd}(\mathrm{mg} / \mathrm{kg})$ & $0.6 \pm 0.07$ & $0.2 \pm 0.04$ & $\mathrm{ND}$ \\
$\mathrm{Zn}(\mathrm{mg} / \mathrm{kg})$ & $176 \pm 2$ & $123 \pm 1$ & $141 \pm 3$ \\
$\mathrm{~Pb}(\mathrm{mg} / \mathrm{kg})$ & $\mathrm{ND}$ & $\mathrm{ND}$ & ${ }^{*} \mathrm{ND}$ \\
$\mathrm{Mn}(\mathrm{mg} / \mathrm{g})$ & $0.447 \pm 0.045$ & $0.587 \pm 0.018$ & $1.25 \pm 0.095$ \\
$\mathrm{Cu}(\mathrm{mg} / \mathrm{kg})$ & $17.5 \pm 0.6$ & $49 \pm 2.1$ & $31.2 \pm 2.3$ \\
$\mathrm{Co}(\mathrm{mg} / \mathrm{kg})$ & $1.314 \pm 0.079$ & $0.895 \pm 0.045$ & $0.187 \pm 0.012$ \\
\hline
\end{tabular}

*concentrations bellow detection limit of the procedure, ND: not detectable.

The lowest value of $\mathrm{K}$ was found in soil derived from the roots zones of Gidole Khat. While the highest concentration of $\mathrm{K}$ in the soil of Konso sample site was recorded. The highest amount of $\mathrm{Ca}$ contents in the soils derived from the root zones of Konso Khat, is highly consistent with its soil $\mathrm{CaCO}_{3} \%$ values ranging from 2.94 to $3.8 \%$. As can be seen from Table 3, the levels of concentrations for metals $\mathrm{Mn}, \mathrm{Zn}$, $\mathrm{Cu}$ and $\mathrm{Cr}$ are in the range $0.447-1.25 \mathrm{mg} / \mathrm{g}, 123-176 \mathrm{mg} / \mathrm{kg}$, $17.49 \mathrm{mg} / \mathrm{kg}$ and $18.11-65.2 \mathrm{mg} / \mathrm{kg}$ respectively. The average concentration of $\mathrm{Mn}$ in the earth's crust is $1000 \mathrm{ppm}$. There are a number of minerals which contain $\mathrm{Mn}$ in sufficient quantity namely, pyrolusite $\left(\mathrm{MnO}_{2}\right)$, hausmannite $\left(\mathrm{Mn}_{3} \mathrm{O}_{4}\right)$, manganite $(\mathrm{MnOOH})$, rhodochrosite $\left(\mathrm{MnCO}_{3}\right)$. It is the second highest amount among the micronutrients in the studied soil next to Fe. However, the amount of Mn in Khat leave is present in lower amount relative to its value in soil. According to Anonymous, 1999; Aubert et al., 2004; Das (2007); Ephrem, 2010; Hagos et al, 2010 and Ayenew et al., 2014, This is due to the fact that the $\mathrm{pH}$ of the studied soil farms ranges from 6.17-8.11. Soils with $\mathrm{pH}$ less than 5.5 may contain a large amount of $\mathrm{Mn}^{2+}$ in the water soluble and exchangeable form. With increasing soil $\mathrm{pH}, \mathrm{Mn}^{2+}$ is converted into its higher oxides $\left(\mathrm{Mn}^{3+}\right.$ and $\left.\mathrm{Mn}^{4+}\right)$ which are insoluble in water and therefore, unavailable to plants.

On the other hand, $\mathrm{Cd}$ and $\mathrm{Co}$ was detected in most of the analyzed soils of farm lands except in koyra farm. The level of the toxic heavy metal $\mathrm{Cd}$ ranges from not detected to 1.2 $\mathrm{mg} / \mathrm{kg}$. The level of $\mathrm{Pb}$, the other tested heavy metal, in the soils of all studied farms was found to be below the detection limit of the method used in this study. Comparing the metal concentration in soil with guidelines for soils showed that all the metal concentration is below the guidelines for soils (Environmental Agency, 2009). This implies that the investigated farm soils are more or less free from heavy metal contamination.

\subsection{Soil pH}

The soil $\mathrm{pH}$ of the farms ranged from 6.17-8.11. Which categorizes the soils from weakly acidic to weakly alkaline. As shown in table 4, soils in Koyra had lower $\mathrm{pH}$ than those from konso or Gidole. The acidic condition in soil may be due to application of NPK fertilizers. The increased use of nitrogenous fertilizers generally increases soil acidity (Miller et al., 2000). Soil $\mathrm{pH}$ is one of the most influential parameters that control conversion of immobile solid-phase metal forms to more mobile and/or bio-available solutionphase forms. The solubility of heavy metals is generally greater as $\mathrm{pH}$ decreases within the $\mathrm{pH}$ range of normal agricultural soils (approximately $\mathrm{pH} 5.0$ to 7.0) (Minalashewa, 2010 and Miller et al., 2000). Therefore high $\mathrm{pH}$ values of soils in this study could have accounted for the low transfer of metals from soil to plants.

\subsection{Amount of Organic Matter}

Organic carbon of the soil was determined by using Walkely and Black method by dichromate oxidation technique (Alloway, 1993). Soil organic matter is oxidized under standard conditions with potassium dichromate in concentrated sulfuric acid. A measured amount of $\mathrm{K}_{2} \mathrm{Cr}_{2} \mathrm{O}_{7}$ is used in excess of that needed to destroy the organic matter and the excess is determined by titration with ferrous ammonium sulfate or ferrous sulfate solution, using 1,10phenanthroline ferrous sulfate indicator to detect the first appearance of unoxidized ferrous ion (Tan, 1996). The organic carbon content of the soil samples were ranged from $2.16 \%$ in Konso to $4.22 \%$ in Koyra. The higher amount of organic matter content of the Koyra soil is probably due to the farmers' use of debris of plant tissues locally known as compost which has higher amount of organic carbon (Miller 2000 and Hagos et al., 2010).

Further, the calcium carbonate content of the soil was determined by acid neutralization method. In this method, soil is treated with excess of standard $\mathrm{HCl}$ to decompose carbonates. The excess acid is back titrated with $0.1 \mathrm{~N} \mathrm{NaOH}$ after filtration. From the amount of acid required to neutralize the carbonate, the $\mathrm{CaCO}_{3}$ equivalent is calculated. The amount of $\mathrm{CaCO}_{3}$ determined is generally higher because some of the acid is used up by exchangeable $\mathrm{Ca}$ and $\mathrm{Mg}$, sodium carbonate if present and possibly also by 
reaction with primary minerals (Tan, 1996).

Table 4. $\mathrm{CaCO}$, Organic matter content and $\mathrm{pH}$ of the khat growing farms.

\begin{tabular}{llll}
\hline \multirow{2}{*}{ Parametres } & \multicolumn{3}{l}{ Sampling site } \\
\cline { 2 - 4 } & Konso & Gidole & Koyra \\
\hline $\mathrm{pH}(\mathrm{H} 2 \mathrm{O})$ at 26 0C & $7.94 \pm 0.11$ & $8.11 \pm 0.02$ & $6.97 \pm 0.07$ \\
$\mathrm{pH}(\mathrm{KCl})$ at 26 0C & $5.97 \pm 0.31$ & $6.97 \pm 0.02$ & $5.83 \pm 0.02$ \\
Organic matter (\%) & $2.16 \pm 0.13$ & $2.96 \pm 0.11$ & $4.22 \pm 0.09$ \\
$\mathrm{CaCO} 3(\%)$ & $2.94 \pm 0.20$ & $3.6 \pm 0.08$ & $0.765 \pm 0.12$ \\
\hline
\end{tabular}

The result from table 4 reveals, calcium carbonate content of the soil was high in Gidole which is $3.6 \%$ and low in Koyra which is $0.765 \%$. This is consistent with the results of the soil acidity in which the moderately alkaline soil of Gidole contains large amount of $\mathrm{CaCO}_{3}$ content, while the acidic soil of Koyra has negligible amount of values of $\mathrm{CaCO}_{3}$ content.

\subsection{Comparison of the Concentration of Identified Metals in Soil and Khat Leaves}

To check associations of the same metal in soil with leaves as well to check whether the ions of one kind present in the soil, either facilitate or interfere with the uptake of the other kind of ions, Pearson Correlation coefficient was used. Thus, Pearson product moment correlation coefficient was calculated. Based on the results of $r$-value, the studied soils were found that correlation coefficients in Koyra and Gidole Khat were lower and, in some cases, not significant, either at 0.05 or at 0.01 level. Some heavy metal concentrations (Fe, $\mathrm{Cr}, \mathrm{Zn}$ and $\mathrm{Mn}$ ) in Khat were negatively correlated with soil $\mathrm{pH}$. Soil $\mathrm{pH}$ is the dominant factor controlling Khat metal uptake. This may be because bioavailability of metals increased with decreasing soil $\mathrm{pH}$. Agronomic practices that reduce soil acidification may be helpful in minimizing the bioavailability of heavy metals in soil, thus resulting in reduced plant uptake and accumulation in plant clones.

The increasing value of $\mathrm{Ca}$ contents in Khat leaves are in accordance with increasing values of $\mathrm{CaCO}_{3} \%$ contents in soil. Interactions among the coexisting elements occurring in the root surface and within the plants also affect their uptake and accumulation in plants (Olowoyo et al., 2010). Metals interact with other metals in the uptake process by the plants. This is because of some metals have similar chemical properties. For example, Mn shows properties of both the alkaline earth cations such as $\mathrm{Mg}^{2+}$ and $\mathrm{Ca}^{2+}$ and the heavy metals $(\mathrm{Zn}, \mathrm{Fe})$. Therefore, it is noted that these ion species affect the uptake and translocation of $\mathrm{Mn}$ in the plants. According to Kraus, (2002) and Santos (2009), with increasing application of potassium the content of $\mathrm{Fe}$ and $\mathrm{Cu}$ decreases in plant tissues. Therefore, the interaction of $\mathrm{K}$ with $\mathrm{Fe}$ and $\mathrm{Cu}$ is antagonistic. $\mathrm{K}$ is negatively interacted with both $\mathrm{Cu}$ and $\mathrm{Fe}$ in Khat leaves. $\mathrm{Zn}$ in this study interacts negatively with that of $\mathrm{Cu}$ and $\mathrm{Mn}$ content in the Khat leaves. The above reports showed that increasing the $\mathrm{Zn}$ content decreases the toxic effect of $\mathrm{Mn}$ and $\mathrm{Cu}$, thus implying a mutual antagonistic effect.

Generally, positive correlations were observed between total metals in soil and Khat leaves metal content for all the elements studied. Correlation coefficients were ranging 0.244-0.951. However, no strong correlations between the leaves and other variables are evident except for $\mathrm{Ca}$ and $\mathrm{Mg}$ metal contents for soil and Khat leaves. This can lead to the probable conclusion that the concentration of metals in the soil measured by the total metal determination method cannot be used as a predictor of metal concentration in Khat leaves. This may be due to the fact that total metal contents of a soil contains all exchangeable metals, carbonate bound metals, oxides bound metals, organic matter bound metals and residues, while metals which are bioavailable for plant uptakes are found in the exchangeable metals. Additionally, Regression analysis was conducted between total metals in soil and Khat leave metal contents to examine their correlation. The total metal values in soil and Khat leaf metal contents fit a linear regression model for all metals studied. However, there was a certain difference in the predicting accuracy among the metals, as $\mathrm{R}^{2}$ ranged from 0.281 for $\mathrm{Mn}$ to 0.991 for $\mathrm{Mg}$. almost all the regression values lye around 0.4 which shows that their correlation is not as much stronger.

\section{Conclusions}

Khat is clearly an important cash crop in Ethiopia wellknown for its foreign currency earnings. Nonetheless, it is little understood and given no development and research attention as yet. This study has helped underline the considerable level of sophistication that characterizes the cultivation and marketing of khat in eastern Ethiopia. In this study the levels of metal in edible portion of khat leaves and their respective soil samples collected from southern region of Ethiopia were analyzed for their contents of $\mathrm{Ca}, \mathrm{Fe}, \mathrm{Mn}$, $\mathrm{Cu}, \mathrm{K}, \mathrm{Zn}, \mathrm{Co}, \mathrm{Cr}, \mathrm{Mg}, \mathrm{Pb}$ and $\mathrm{Cd}$ using flame atomic absorption spectrometer. The optimized wet digestion method for the analysis of samples was found efficient for all the metals and it was evaluated through the recovery experiment and a good percentage recovery of 90 to $110 \%$ was obtained for all the metals identified.

Based on the results of this study, higher amounts of $\mathrm{K}$ and Fe among the determined macro- and micronutrient metals respectively for both Khat leaves and soils. Heavy metals $\mathrm{Cr}$ and $\mathrm{Cu}$ were found to be comparatively at lower levels in most of the soil and Khat samples. Concentrations of $\mathrm{K}, \mathrm{Ca}$ and $\mathrm{Mg}$ in the edible leaves of Khat plants decreased in the order: $\mathrm{K}>\mathrm{Mg}>\mathrm{Ca}$. While for the soils the order is; $\mathrm{Fe}>$ $\mathrm{K}>\mathrm{Mg}$. Heavy metal contents in all Khat samples could be arranged in descending order: $\mathrm{Fe}>\mathrm{Zn}>\mathrm{Mn}>\mathrm{Cu}>\mathrm{Cr}$. While for soil samples the order is $\mathrm{Fe}>\mathrm{Mn}>\mathrm{Zn}>\mathrm{Cu}>\mathrm{Cr}$. The levels of $\mathrm{Cd}$ and $\mathrm{Pb}$ in all Khat samples were too low to be detected by the method used in this study. However, their absence in the studied Khat plants of the farms may not necessarily guarantee the non-existence of these toxic metals in the different commercial Khat plants available in markets. Further, the total metal values in soil and Khat leaf essential and non-essential metal contents fit a linear regression model for all metals studied. However, there was a certain 
difference in the predicting accuracy among the metals, as $\mathrm{R}^{2}$ ranged from 0.281 for $\mathrm{Mn}$ to 0.991 for $\mathrm{Mg}$.

Finally, the overall results of this study suggest that there were significant variations in the level of some elements between the khat varieties which could be attributed to different factors such as age of the harvest khat, geographical and climatical variation, difference in physicochemical nature of the soil, and different agricultural practices among khat cultivars.

\section{Acknowledgements}

The authors are grateful to the Department of Chemistry, College of Natural Sciences, Arbaminch University, Arbaminch, Ethiopia for proving laboratory facilities. We are thankful to our students (graduating class of 2014) for helping in sample collection and laboratory work.

\section{References}

[1] Alloway, B.J., 1993. Heavy metals in soils. Blackie Academic, Great Britain.

[2] Anonymous, 1999. Total diet study: aluminum, arsenic, cadmium, chromium, copper, lead, mercury, nickel, selenium, tin, and zinc. Journal of Food Surveillance Information. 1: 191.

[3] Aubert, D., A. Probst and P. Stille, 2004. Distribution and origin of major and trace elements in to labile and residual phases in acid soil profile (Vosges Mountains, France). $J$. Appl. Geochem. 19: 899-916.

[4] Ayenew A, Gebremariam B., Ephrem E., 2014. Levels of Essential and Toxic Metals in Ethiopian Khat, (catha edulis Forsk.) Ethiopian Journal of Environmental Studies \& Management 7(3): 289 - 297, 2014.

[5] Belew, M., Kebede, D., Kassaye, M. and Enguoselassie, F. (2000). The magnitude of khat use and its association with health, nutrition and socio-economic status. Ethiopian Medical Journal, 38:11-26.

[6] Das, K. D., 2007. Micronutrients: Their Behaviour in Soil and Plants. $2^{\text {ed }}$, Newdelhi, India.

[7] Ephrem T. Woldemariam, 2010, Trace metals in Ethiopian Khat.: Determination of trace metals in commercially available Khat (Catha edulis Forsk) in Addis Ababa, VDM Verlag.

[8] Erica E. Balint, 2012. Khat (Catha Edulis) A Controversial Plant: Blessing or Curse?, A Thesis submitted for the Degree of Doctor of Philosophy in University of Szeged, Szeged, Hungary
[9] Hagos T., M. Redi and A. Taddese, 2010. Correlation between Khat (Catha Edulis Forsk) Leaves and Soil Composition in Hararghe Region, Haramaya University, Ethiopia

[10] Jackson, M.L., 1970. Soil Chemistry Analysis. Prentice-Hall Inc. Englewood Cliffs, N.J.Sixth printing. pp498.

[11] Krauss, M. Wilfgang, W. Kobza, and J. Zech, 2002. Predicting heavy metal transfer from soil to plant: potential use of Freundlich-type functions. Journal of Plant Nutrition and Soil Science. 165: 3-8.

[12] Milanovic, B. (2008). Qat expenditures in Yemen and Djibouti: An empirical analysis. Journal of African Economies, 17:661.

[13] Miller, D.M. and W.P. Miller, 2000. Land application of waste. In: Summer, M.E. (Ed.). Handbook of Soil Science. CRC Books, New York.

[14] Minaleshewa, A., B.S. Chandravanshi and R. Mesfin, 2010. Concentration levels of Essential and Non-essential Metals in Ethiopian Khat (Catha edulis Forsk). Bio. Trace. Elements.

[15] Minaleshewa, A. and B.S. Chandravanshi, 2008. Levels of major, minor and trace elements in commercially available enset(Ensete ventricosum (Welw.), Cheesman) food products ( Kocho and Bulla) in Ethiopia. Journal of food composition and Analysis. 21:545-552.

[16] Olowoyo, J.O., E. van Heerden, J.L. Fischer and C. Baker, 2010. Trace metals in soil and leaves of Jacaranda mimosifolia in Tshwane area, South Africa. Atmospheric Environment. 44: 1826-1830.

[17] Peters, D.W., 1952. Khat: Its history, botany, chemistry and toxicology. J. of Pharm. 196:16-18 \& 36-7.

[18] Rodushkin, I., T. Ruth and A. Huhtasaari, 2007. Comparison of two digestion methods for elemental determinations in plant material by ICP techniques. J. Anal. Chim. Acta. 378: 191-200.

[19] Santos, J.S., M.L. Santos, M.M. Conti, S.N. Santos and E. Oliveira, 2009. Evaluation of some metals in Brazilian coffees cultivated during the process of conversion from conventional to organic agriculture. Food Chemistry. 115: 1405-1410.

[20] Sapkota, A., M. Krachler, C. Scholz, A. K. Cheburkin and W. Shotyk, 2005. Analytical procedures for the determination of selected major (Al, Ca, Fe, K, Mg, Na, and Ti) and trace ( $\mathrm{Li}$, $\mathrm{Mn}, \mathrm{Sr}$, and $\mathrm{Zn}$ ) elements in peat and plant samples using inductively coupled plasma-optical emission spectrometry. Analytica Chimica Acta. 540: 247-256.

[21] Szendrei, K., 1980. The chemistry of Khat. J.Bull Narc. 32:536.

[22] Tan, K. H., 1996. Soil Sampling Preparation and Analysis. Marcel Dekker, Inc., New York, pp 96-219. 